See discussions, stats, and author profiles for this publication at: https://www.researchgate.net/publication/270215322

The relationship between temperament and character features, and social problem solving in psychiatric patients who attempted suicide with drugs: Preliminary results

Article in Anadolu Psikiyatri Dergisi · March 2014

DOI: $10.5455 /$ apd. 43668

6 authors, including:

Ibrahim Taymur

Bursa Şevket Yilmaz Training and Research Hospital

46 PUBLICATIONS 109 CITATIONS

SEE PROFILE

2. Veli Duyan

Ankara University

74 PUBLICATIONS 413 CITATIONS

SEE PROFILE

Some of the authors of this publication are also working on these related projects:

Ostim PTSD project View project

Suicide and its cognitive behavioral base View project
27. Kadir Ozdel

University of Health Sciences, Diskapi Yildirim Beyazit Teaching and Research Hos... 48 PUBLICATIONS 90 CITATIONS

SEE PROFILE

Emre Sargın

Üsküdar University

24 PUBLICATIONS 52 CITATIONS

SEE PROFILE 


\title{
The relationship between temperament and character features, and social problem solving in psychiatric patients who attempted suicide with drugs: preliminary results
}

\author{
İbrahim TAYMUR, ${ }^{1}$ Kadir ÖZDEL, ${ }^{2}$ Veli DUYAN, ${ }^{3}$ \\ A. Emre SARGIN, ${ }^{4}$ Gökçe DEMIRAN, ${ }^{2}$ M. Hakan TÜRKÇAPAR ${ }^{5}$
}

\begin{abstract}
Objective: In order to gather information in a broader sample, the aims of this preliminary study were: 1) to identify psychiatric diagnoses and any history of suicidal thoughts and attempts in people who attempt suicide with drugs, 2) to evaluate the temperament and character features, social problem solving skills of these patients in relation to sociodemographic data and 3) to analyze the correlations between these factors. Methods: Sixty patients between 16 and 49 years old participated in this study. A Structured Clinical Interview for DSM-IV Axis I Disorders (SCID-I), a Sociodemographic Data Form, the Beck Depression Inventory (BDI), Temperament and Character Inventory (TCI) and Social Problem Solving Inventory (SPSI) were administered to the participants. Results: According to the SCID-I, 23 (38.3\%) of the participants had a major depressive disorder, and 39 (65\%) of the participants had a history of previous suicide attempts before this admission. There was a significant relationship between self-esteem scores and the incidence of previous suicide attempts. There were significant (negative) correlations between the harm avoidance, reward dependence, self-directedness and cooperativeness dimensions of the $\mathrm{TCl}$ and the problem orientation and problem solving skills subscales of the SPSI. Conclusion: Psychiatric disorders are common in individuals who attempt suicide with drugs. These individuals may have a history of one or more suicide attempts before admission. In addition to differences in temperament and character features, this study found significant disorders of cognition and behavior in individuals that had attempted suicide. This result may indicate that dimensions of temperament and character can provide significant indications for cognitive and behavioral disorders. (Anatolian Journal of Psychiatry 2014; 15:31-38)
\end{abstract}

Key words: suicide, social problem solving, temperament, character

\section{İlaçla intihar girişiminde bulunan bireylerde mizaç ve karakter özellikleri ile sosyal sorun çözme arasındaki ilişkiler: Öncü sonuçlar}

ÖZET

Amaç: Bu öncü çalışmanın amaçları, 1) ilaçla intihar girişiminde bulunan kişilerde önceki intihar girişimi ve düşüncelerinin saptanması ve psikiyatrik tanılarının belirlemek, 2) bu hastaların sosyodemografik özellikleri ile sosyal sorun çözme ve mizaç karakterleri arasındaki ilişkiyi saptamaktır. Yöntem: Çalışmaya 16-49 yaşları arasındaki 60 hasta alınmıştır. Veriler DSM-IV Eksen I tanıları için Yapılandırılmış Klinik Görüşme (SCID-I), Sosyodemografik

\footnotetext{
${ }^{1}$ Şevket YIlmaz Training and Research Hospital, Bursa

2 Diskapi Training and Research Hospital, Ankara

${ }^{3}$ Ankara University, Faculty of Health Science, Ankara

${ }^{4}$ Neuropsychiatrylstanbul, İstanbul

${ }^{5}$ Kalyoncu University, İstanbul

Yazışma adresi/ Address for correspondence:

Dr. İbrahim TAYMUR, Şevket Yılmaz Egitim Arastirma Hastanesi Psikiyatri Klinigi, Yıldırım-Bursa/Turkey

E-mail: dritay@yahoo.com

Geliş tarihi: 07.02.2013, Kabul tarihi: 02.09.2013 doi: 10.5455/apd.43668
} 
Veri Formu, Beck Depresyon Ölçeği, Mizaç Karakter Ölçeği (MKÖ) ve Sosyal Sorun Çözme Ölçeği (SSÇÖ) ile toplanmıştır. Bulgular: SCID-I ile uyumlu olarak hastaların 23'ü (38.3\%) majör depresif bozuk-luğa sahip olduğu, 39 'unun (65\%) hastaneye başvurmadan önce en az bir intihar girişimi öyküsünün bulunduğu saptanmıştır. MKÖ'nün zarardan kaçınma, ödül bağımlıı̆̆ı, kendini yönlendirme ve işbirliği boyutları ile SSÇE'nin sorun yönelimi ve sorun çözme becerileri arasında ters yönde anlamlı ilişki belirlenmiştir. Tartışma: Ilaçla intihar girişiminde bulunmuş bireylerde psikiyatrik tanılar yaygın olarak görülmektedir. Bu bireylerin hastaneye kabulden önce en az bir intihar girişimi öyküsü bulunmaktadır. Intihar girişiminde bulunan bireyler, mizaç ve karakter özelliklerindeki farklııklara ek olarak anlamlı düzeyde biliş ve davranış bozuklukları sergilemektedir. Bu çalışma, mizaç ve karakter boyutlarının bilişsel ve davranışsal bozuklukları belirlemek için önemli bir veri sağladığını ortaya koymaktadır. (Anadolu Psikiyatri Derg 2014; 15:31-38)

Anahtar sözcükler: Intihar, mizaç, karakter, sosyal sorun çözme

\section{INTRODUCTION}

Suicidal behavior is defined as including thoughts of suicide, suicide attempts and completed suicide. Suicide is among the most common and significant of all causes of death. ${ }^{1,2}$

Factors that predispose individuals to suicidal behaviors can be considered according to several specific concepts. Patients' problem solving skills are reported to be an important factor in predicting suicidal behaviors. ${ }^{3,4}$ Especially in adolescents, the elevation of stress levels along with the deterioration of problem solving skills increases the risk of suicidal thoughts and nonfatal suicide attempts. ${ }^{5-7}$ Although it was clear that the deterioration of problem solving skills is associated with depression and increased the risk of suicidal behaviors in teenagers and adults, the nature of this deterioration and who was most likely to show it was not clear. ${ }^{8}$

Problem solving skills are defined here within the framework of the cognitive behavioral approach. According to this model there is a negative correlation between suicidal behaviors and problem solving skills. ${ }^{9,10}$ This social problem solving model defines cognitive, emotional and behavioral processes conceptualized as 'problem orientation' and 'problem solving skills'. 'Problem orientation' indicates an individual's level of awareness about a problem; evaluates his/her problem solving skills; and predicts his/her efficacy in attempting to solve the problem. 'Problem solving skill' is defined as an individual's ability to define problems, to generate logical solutions, and to monitor the results of those solutions. ${ }^{11-14}$

Temperamental and characterological issues are also important to the suicidal behavior. ${ }^{15}$ Cloninger describes them using two-dimension scale. Studies of suicidal behavior using this model show that an increase in the temperamental traits of novelty seeking, harm avoidance and reward dependence, and an increase in the character dimension of self-transcendence along with a decrease in cooperation and self-management can be correlated with suicide attempts and suicidal thoughts. ${ }^{16-19}$

To date, there has been no other study that has assessed temperament, character and social problem solving skills together. The aim of this study is to assess the correlations between temperament and character features and social problem solving skills in individuals who attempt suicide with drugs.

\section{METHODS}

This study was the preliminary part of the multicentric research. Sixty individuals participated in this study. They were between the ages of 16 and 49, and were admitted to Ankara Diskapi YB Education and Research Hospital Emergency Service due to suicide attempts with drugs. The inclusion criteria for the study were a patient's agreement to participate, and their treatment and observation within the emergency service. The exclusion criteria for the study were a cognitive disability that might interfere with answering assessment scales, and the presence of acute psychotic disorders. The study was approved by the institution's Ethics Committee and written informed consent was obtained from each participant.

\section{Data collection tools}

The Structured Clinical Interview for DSM-IV Axis I Disorders (SCID-I): This is a structured clinical interview form developed by Spitzer et al. to diagnose DSM-IV Axis I disorders. ${ }^{20}$ Validity and reliability was established for the Turkish test by Özkürkçügil et al. ${ }^{21}$

Beck Depression Inventory (BDI): This 21item scale was developed by Beck. ${ }^{22}$ For the Turkish version of this test, the cut off point for validity and reliability is considered to be $17 .^{23}$

The Temperament and Character Inventory 
(TCl): This test was developed by Cloninger and colleagues ${ }^{24}$ and its Turkish validity and reliability was established by Köse et al. ${ }^{25}$ There are four temperament and three personality dimensions in this inventory. Temperament dimensions: novelty seeking (NS), exploratory excitability $\left(\mathrm{NS}_{1}\right)$, impulsiveness $\left(\mathrm{NS}_{2}\right)$, extravagance $\left(\mathrm{NS}_{3}\right)$, disorderliness $\left(\mathrm{NS}_{4}\right)$, harm avoidance $(\mathrm{HA})$, anticipatory worry $\left(\mathrm{HA}_{1}\right)$, fear of uncertainty $\left(\mathrm{HA}_{2}\right)$, shying away $\left(\mathrm{HA}_{3}\right)$, fatigue $\left(\mathrm{HA}_{4}\right)$, reward dependence (RD), sentimentality $\left(R D_{1}\right)$, attachment $\left(R D_{2}\right)$, dependence $\left(R D_{3}\right)$, persistence $(P)$; character dimensions: selfdirectedness $(S)$, responsibility $\left(S_{1}\right)$, purposefulness $\left(S_{2}\right)$, resourcefulness $\left(S_{3}\right)$, self-acceptance $\left(S_{4}\right)$, adjusted secondary temperament $\left(S_{5}\right)$, cooperativeness $(C)$, social acceptance $\left(C_{1}\right)$, empathy $\left(C_{2}\right)$, helpfulness $\left(C_{3}\right)$, compasssion $\left(C_{4}\right)$, pure-hearted conscience $\left(C_{5}\right)$, selftranscendence (ST), self-forgetfulness $\left(\mathrm{ST}_{1}\right)$, metapersonal identification $\left(\mathrm{ST}_{2}\right)$, and spiritual acceptance $\left(\mathrm{ST}_{3}\right)$.

The Social Problem Solving Inventory-SPSI: The SPSI developed by D'Zurilla and Nezu. ${ }^{26}$ The validity and reliability of the Turkish version was established by Duyan and Gelbal. ${ }^{27}$ This is a 70-item multi-dimensional measurement tool. Every item in this inventory consists of statements that reflect either positive (promoter) or negative (inhibitive) cognitive, emotional and behavioral reactions to problem solving situations in daily life. The SPSI has two primary scales, the Problem Orientation Scale (POS-30 items) and the Problem Solving Skills Scale (PSSS-40 items). The SPSI has 7 subscales of 10 items. The three subscales of the POS are cognitive, sensory and behavioral subscales. The four subscales of the PSSS are: 1) problem identification and formulation, 2) generating alternative solutions, 3 ) decision making and 4) solution implementation and verification. Subjects are asked to rate answers on a five point scale: 'never true for me'-0 point to 'always true for me'-4 points with the higher the score, the better the subject's social problem solving capacity.

\section{Statistical analysis}

Study data were analyzed using the SPSS, version 16.0. The independent samples t-test procedure was employed to compare the means for the two sets of cases. We also employed Pearson correlation coefficients to determine the relationships between dependent and independent variables. The minimum acceptable level of significance was set at .05. Additionally, to control the family-wise error rate we used Bonferroni Correction while setting a significance level for multiple comparisons. Accordingly significance level was set as $p<$ 0.007 for comparisons.

Table 1. Sociodemographic features and Beck Depression Inventory scores ratios of individuals who attempted suicide with drugs

\begin{tabular}{|c|c|c|c|c|c|}
\hline & & $\mathrm{n}$ & $\%$ & $\begin{array}{l}\text { epression Inventory } \\
\text { Ort. } \pm \text { SD }\end{array}$ & $\mathrm{p}$ \\
\hline Gender & $\begin{array}{l}\text { men } \\
\text { women }\end{array}$ & $\begin{array}{l}16 \\
44\end{array}$ & $\begin{array}{l}26.7 \\
73.3\end{array}$ & $\begin{array}{l}20.8 \pm 15.8 \\
30.3 \pm 13.4\end{array}$ & $0.024^{*}$ \\
\hline Marital status & $\begin{array}{l}\text { single } \\
\text { married } \\
\text { divorced }\end{array}$ & $\begin{array}{r}32 \\
25 \\
3\end{array}$ & $\begin{array}{r}53.3 \\
41.7 \\
5.0\end{array}$ & $\begin{array}{l}23.8 \pm 13.0 \\
31.8 \pm 15.1 \\
42.3 \pm 13.5\end{array}$ & $0.035^{*}$ \\
\hline Education level & $\begin{array}{l}\text { primary school } \\
\text { secondary school } \\
\text { high school } \\
\text { university }\end{array}$ & $\begin{array}{r}7 \\
15 \\
32 \\
6\end{array}$ & $\begin{array}{l}11.7 \\
25.0 \\
53.3 \\
10.0\end{array}$ & $\begin{array}{l}39.4 \pm 10.5 \\
30.6 \pm 15.7 \\
24.3 \pm 13.0 \\
25.5 \pm 18.3\end{array}$ & $0.071^{*}$ \\
\hline Working status & $\begin{array}{l}\text { employed } \\
\text { unemployed }\end{array}$ & $\begin{array}{l}24 \\
36\end{array}$ & $\begin{array}{l}40.0 \\
60.0\end{array}$ & $\begin{array}{l}23.4 \pm 14.7 \\
30.6 \pm 13.9\end{array}$ & $0.059^{*}$ \\
\hline Suicidal thoughts & $\begin{array}{l}\text { lifetime } \\
\text { in last } 12 \text { months } \\
\text { present } \\
\text { none }\end{array}$ & $\begin{array}{r}9 \\
22 \\
15 \\
14\end{array}$ & $\begin{array}{l}15.0 \\
36.7 \\
25.0 \\
23.3\end{array}$ & $\begin{array}{l}31.3 \pm 12.1 \\
28.6 \pm 14.0 \\
28.0 \pm 11.9 \\
23.9 \pm 19.4\end{array}$ & $0.671^{*}$ \\
\hline Suicide attempt & $\begin{array}{l}\text { lifetime } \\
\text { in last } 12 \text { months } \\
\text { none }\end{array}$ & $\begin{array}{l}11 \\
28 \\
21\end{array}$ & $\begin{array}{l}18.3 \\
46.7 \\
35.0\end{array}$ & $\begin{array}{l}30.3 \pm 12.8 \\
29.5 \pm 14.8 \\
24.1 \pm 14.9\end{array}$ & $0.373^{*}$ \\
\hline Suicide attempt in family & $\begin{array}{l}\text { yes } \\
\text { no }\end{array}$ & $\begin{array}{r}9 \\
51\end{array}$ & $\begin{array}{l}15.0 \\
85.0\end{array}$ & $\begin{array}{l}32.4 \pm 15.3 \\
26.9 \pm 14.4\end{array}$ & $0.304^{*}$ \\
\hline
\end{tabular}

* Significance level was set at 0.007 for group comparisons 


\section{RESULTS}

A total of 60 participants were included in the study. The sociodemographic data including gender, marital status, education level, previous suicide attempts and a history of a suicide attempt in the family can be seen in Table 1. BDI scores indicated no significant differences between the genders and according to marital status, education level, working status, previous suicidal thoughts, previous suicide attempts and a history of suicide (Table 1).

According to the psychiatric evaluation using SCID-I, 7 (11.6\%) of the participants showed no psychiatric diagnosis. On the other hand, 23 $(38.3 \%)$ of them had major depressive disorder (MDD), 20 (33.3\%) had an adjustment disorder (AD), $13(21.6 \%)$ had generalized anxiety disorder (GAD), 10 (16.6\%) had post-traumatic stress disorder (PTSD), 5 (8.3\%) had schizophrenia $(\mathrm{SCH}), 5(8.3 \%)$ had dissociative dis-

Table 2. Correlation findings between the Temperament and Character Inventory the Social Problem Solving Inventory

\begin{tabular}{|c|c|c|c|c|c|c|c|}
\hline & \multicolumn{3}{|c|}{ Problem Orientation Scale } & \multicolumn{4}{|c|}{ Problem Solving Skills Scale } \\
\hline & Cognition & Emotion & Behavior & Identification & $\begin{array}{l}\text { Generating } \\
\text { alternatives }\end{array}$ & $\begin{array}{l}\text { Decision } \\
\text { making }\end{array}$ & $\begin{array}{l}\text { Solution } \\
\text { implementation }\end{array}$ \\
\hline \multicolumn{8}{|c|}{ Temperament s of $\mathrm{TCl}$} \\
\hline (NS) & -0.093 & -0.038 & -0.031 & -0.041 & -0.234 & -0.231 & -0.143 \\
\hline$(\mathrm{HA})$ & $-0.443^{* * *}$ & -0.081 & -0.189 & -0.186 & $-0.359^{* *}$ & $-0.492^{* * *}$ & $-0.363^{* *}$ \\
\hline (RD) & $-0.279^{*}$ & -0.001 & -0.004 & -0.193 & -0.180 & $-0.334^{* *}$ & $-0.261^{*}$ \\
\hline$(\mathrm{P})$ & -0.146 & -0.088 & -0.031 & -0.044 & -0.212 & -0.219 & -0.218 \\
\hline \multicolumn{8}{|c|}{ Character features of $\mathrm{TCl}$} \\
\hline (S) & $-0.476^{* * *}$ & $-0.548^{* * *}$ & $-0.415^{\star *}$ & 0.149 & -0.209 & $-0.469^{* * *}$ & -0.055 \\
\hline (C) & $-0.293^{*}$ & $-0.277^{*}$ & -0.246 & -0.015 & -0.251 & $-0.424^{\star *}$ & -0.084 \\
\hline (ST) & -0.214 & -0.249 & -0.078 & -0.082 & -0.210 & $-0.274^{*}$ & -0.198 \\
\hline \multicolumn{8}{|c|}{ Novelty seeking subscales } \\
\hline (NS1) & -0.201 & 0.000 & 0.066 & -0.224 & $-0.362^{* *}$ & $-0.313^{*}$ & $-0.345^{\star *}$ \\
\hline (NS2) & -0.085 & -0.074 & -0.051 & -0.088 & -0.206 & $-0.257^{*}$ & -0.221 \\
\hline (NS3) & -0.010 & -0.126 & $-0.272^{*}$ & 0.169 & 0.059 & -0.035 & 0.221 \\
\hline (NS4) & 0.040 & 0.068 & 0.113 & 0.060 & -0.106 & -0.027 & 0.001 \\
\hline \multicolumn{8}{|c|}{ Harm avoidance subscales } \\
\hline (HA1) & $-0.347^{* *}$ & 0.002 & -0.161 & -0.187 & $-0.301^{*}$ & $-0.433^{* *}$ & -0.242 \\
\hline (HA2) & $-0.291^{*}$ & -0.176 & -0.113 & 0.070 & 0.006 & -0.203 & -0.131 \\
\hline (HA3) & -0.236 & 0.029 & -0.188 & -0.096 & $-0.262^{*}$ & -0.253 & -0.229 \\
\hline (HA4) & $-0.393^{* *}$ & -0.128 & -0.084 & $-0.274^{*}$ & $-0.433^{* *}$ & $-0.480^{* * *}$ & $-0.429^{* *}$ \\
\hline \multicolumn{8}{|c|}{ Reward dependence subscales } \\
\hline (RD1) & -0.230 & -0.071 & -0.055 & -0.150 & -0.148 & -0.235 & -0.147 \\
\hline (RD2) & $-0.270^{*}$ & -0.134 & -0.055 & -0.071 & -0.191 & $-0.271^{*}$ & -0.240 \\
\hline (RD3) & 0.069 & $0.298^{*}$ & 0.171 & -0.156 & 0.018 & -0.060 & -0.125 \\
\hline \multicolumn{8}{|c|}{ Self directedness subscales } \\
\hline (S1) & $-0.275^{*}$ & $-0.551^{* * *}$ & $-0.495^{\star * *}$ & $0.329^{* *}$ & -0.003 & $-0.261^{*}$ & 0.071 \\
\hline (S2) & $-0.377^{* *}$ & -0.210 & -0.159 & -0.073 & $-0.281^{*}$ & $-0.351^{* *}$ & -0.174 \\
\hline (S3) & $-0.298^{*}$ & $-0.386^{* *}$ & $-0.458^{* * *}$ & $0.264^{*}$ & 0.036 & $-0.261^{*}$ & 0.122 \\
\hline (S4) & $-0.369^{\star *}$ & $-0.380^{* *}$ & -0.214 & -0.018 & $-0.265^{\star}$ & $-0.420^{\star *}$ & -0.109 \\
\hline (S5) & -0.233 & $-0.265^{*}$ & -0.103 & 0.058 & -0.095 & -0.201 & -0.034 \\
\hline \multicolumn{8}{|c|}{ Cooperativeness subscales } \\
\hline (C1) & -0.168 & -0.198 & $-0.269^{*}$ & -0.058 & -0.226 & $-0.287^{*}$ & -0.022 \\
\hline (C2) & -0.169 & $-0.347^{* *}$ & -0.217 & 0.186 & -0.130 & -0.250 & 0.091 \\
\hline (C3) & $-0.274^{*}$ & -0.020 & -0.029 & -0.206 & -0.248 & $-0.335^{\star *}$ & -0.239 \\
\hline (C4) & -0.132 & -0.182 & -0.109 & 0.086 & -0.010 & -0.158 & 0.075 \\
\hline (C5) & -0.135 & -0.072 & -0.095 & -0.079 & -0.195 & $-0.276^{*}$ & -0.206 \\
\hline (ST1) & -0.091 & $-0.350^{* *}$ & -0.091 & 0.075 & -0.086 & -0.157 & -0.037 \\
\hline (ST2) & -0.048 & 0.121 & 0.090 & -0.205 & -0.180 & -0.158 & -0.145 \\
\hline (ST3) & $-0.336^{* *}$ & $-0.279^{*}$ & -0.154 & -0.087 & -0.219 & $-0.302^{*}$ & $-0.274^{*}$ \\
\hline
\end{tabular}

${ }^{*} p<0.05,{ }^{* *} p<0.01,{ }^{* * *} p<0.001$ 
order (DD), 4 (6.6\%) had social phobia (SP), 3 $(5 \%)$ had obsessive-compulsive disorder (OCD), 2 (3.3\%) had dysthymia (D), 2 (3.3\%) had alcohol abuse (AA) and 1 (1.6\%) had bipolar disorder (BB).

A significant negative correlation was found between the $\mathrm{HA}$ subscale of $\mathrm{TCl}$ and the cognition, generating alternatives, solution implementation, and decision making subscales of the SPSI. There were also significant correlations between $\mathrm{HA}_{1-4}$ and some subscales of the SPSI. There was no significant correlation between NS on the $\mathrm{TCl}$ and the SPSI subscales. But there was a significant correlation between the $\mathrm{NS}_{1-3}$ and some subscales of the SPSI.

Another significant negative correlation was found between the cognition, solution implementation, generating alternatives subscales of the SPSI and the RD subscale of the TCl. Significant correlations were found between the $\mathrm{RD}_{2-3}$ and the subscales of the SPSI (Table 2).

A significant negative correlation was found between the $S$ subscales and the cognition, emotion, behavior and solution implementation subscales of the SPSI. There was a meaningful correlation between the $S_{1-5}$ and some subscales of the SPSI. A significant negative correlation was found between the $C$ dimension of the $\mathrm{TCl}$ and the cognition, emotion, and solution implementation subscales of the SPSI. Also a significant correlation was found between the $\mathrm{C}_{1-5}$ and the some subscales of SPSI. Finally, a meaningful negative correlation was found between the ST dimension (TCl) and the decision making subscale of the SPSI. Another significant correlation was established between the $\mathrm{ST}_{1,3}$ subscales and some subscales of the SPSI (Table 2).

\section{DISCUSSION}

In this study our aims were to: 1) determine clinical and sociodemografic features including psychiatric diagnoses, previous suicidal thoughts and suicide attempts for people who attempted suicide with drugs, 2) evaluate these people in terms of temperament and character feature and a social problem solving skills and 3) to analyze the correlations between these parameters.

When the sociodemographic data were evaluated, we found that $88.4 \%$ of participants had at least one psychiatric disorder. Psychiatric diagnoses in order of frequency were: MDD, AD, GAD and PTSD. Mental disorders, especially
MDD, reflect a predisposition to suicidal thoughts and attempts. ${ }^{28}$ While mood disorders are the main risk factors that have been identified in developed countries, in developing countries, impulse control disorders, SA and PTSD have been demonstrated to be the primary risk factors. ${ }^{29}$

In our study $76.7 \%$ of the participants reported previous suicidal thoughts, $65 \%$ of them had a history of at least one previous suicide attempt. Several follow-up studies show that individuals who attempt suicide also report previous suicidal thoughts and suicide attempts. ${ }^{30-32}$

In our study we evaluated cognitions and behaviors related to coping, using the SPSI, for subjects who had attempted suicide. The POS measures the meta-cognitive processes of an individual. In one way, a problem orientation can be adaptive, providing motivational, attitudinal, and affective abilities for solving problems that may increase the effectiveness of an individual when solving a particular problem. ${ }^{33}$ The ability to solve a problem which is measured by PSSS indicates cognitive and behavioral activities directed toward understanding the problem and toward finding efficient solutions and implementing them. ${ }^{34}$

In the literature, the $\mathrm{TCl}$ and the SPSI have been used separately, but no study has considered how these features show correlations with each other in persons who attempt suicide. In our study, we demonstrated many correlations between these two scales. Temperamental subscales such as $\mathrm{HA}$ and $\mathrm{RD}$ and characterological subscales such as $\mathrm{S}, \mathrm{C}$ and ST were somewhat correlated with SPSI subscales.

We found significant correlations between the $\mathrm{RD}$ and $\mathrm{HA}$ dimensions of the $\mathrm{TCl}$ and the two dimensions of the SPSI. According to Cloninger, the Temperament subscale shows prejudices and tendencies that are parts of perceptual memory and are independent of sociocultural attributes during the early stages of life. ${ }^{35}$ Temperament is the integration of skills and routines related to emotions by perception, linkage and motivation processes. ${ }^{37-39}$

HA has a strong negative correlation with cognition item of problem orientation subscale and decision making subscale of PSSS alongside a moderate correlation with generation alternatives and solution implementation items. These findings suggest, at least in suicide attempters, that harm avoidance is related with behavioral

Anadolu Psikiyatri Derg 2014; 15:31-38 
components of the problem solving as well as cognitive component of problem orientation. This is consistent with the negative problem orientation concept which is described by D'Zurilla as one's lack of commitment to solving problems and avoiding them. ${ }^{40}$ However harm avoidance is state dependent in depression and the higher score of harm avoidance is not specific to any psychopathology since the same result has been observed in various clinical states. ${ }^{41}$ Rather higher score on this dimension could reflect the severity of general psychopathology and could constitute a personality risk to develop general adjustment deterioration with poor problem solving skills. Another temperamental item which is correlated weakly to moderately with the same SPSI subscales except 'generating alternatives' item is RD. Reward dependence is characterized as sentimentality, tender-heartedness, social sensitivity, attachment and dependence on approval of others. This temperamental feature is related to suggestibility and loss of objectivity. According to our findings high reward dependency is related to more dysfunctional cognitive appraisals to a problem along with poor decision making and solution implementation skills.

$\mathrm{HA}$ is the temperament dimension most affected by MDD and it shows an increase in people who attempt suicide. ${ }^{13-18}$ Cognitive beliefs and internalization processes connected to the HA dimension may affect individual's perceptions of social problems and their ability to find efficient solutions. One study on this question found that individuals who have high $\mathrm{HA}$ and low $\mathrm{S}$ and $\mathrm{C}$ features, demonstrate defects in their cognitive executive functions. Similarly, a visualization study showed a significant relationship between RD and cognitiveemotional responses. ${ }^{42}$ Individuals who score high on RD have a tendency to build warm and lasting relationships. They are also reported to show intense emotional reactions after the loss of an object and separations. They may also be highly affected by other people. ${ }^{36}$ This malleability and reactivity toward life events may be associated with disturbances in cognition and the enacting dimensions of the SPSI.

Although there was no correlation between the NS in general and SPSI there were meaningful correlations between problem solving skill subscales and exploratory excitement, extravagance and impulsiveness items. Exploratory excitement which is supposed as the opposite of 'stoic rigidity'24 seems to be mainly related to problem solving skills rather than problem Anatolian Journal of Psychiatry 15:31-38 orientation.

We found a significant correlation between the $\mathrm{S}$ and $\mathrm{C}$ scores of the $\mathrm{TCl}$ and the two areas of the SPSI. Cloninger defines 'character extension' as the selfhood concepts individuals learn through interactive relationships with others and their insight into these concepts. However, he indicated that insight into selfhood concepts develop in the adulthood stage ${ }^{35}$ Character is correlated with propositional memory, which includes high level cognitive processes like symbollization and abstraction. ${ }^{37}$ Almost the strongest correlations detected in the current study are between self directedness character feature and problem orientation processes. Individuals who score low on the $\mathrm{S}$, also endorse features like not being able to take responsibility for their choices and decisions, difficulty with goal setting, diffidence, emotional fragility and immaturity. ${ }^{35}$ Accordingly we detected strong correlations between Responsibility item of $S$ and emotional \& behavioral problem orientation of POS. Our findings related to $S$ may help explain the correlation between suicide attempts and deficits in problem solving for people who endorse this character dimension.

In this study, the significant correlations between the HA, RD, $S$ and $C$ dimensions of the $\mathrm{TCl}$ and SPSI, show similarities with the findings that show differences in temperament and character features between those individuals who attempt suicide and those who do not. This finding may demonstrate that temperament and character features reflect significant cognitive and behavioral disorders. One study conducted about this issue found that the Temperament and Character features affected by depressive disorders showed significant correlations with the questions about cognition in the BDI. ${ }^{43}$

\section{CONCLUSION}

Individuals who attempt suicide with drugs also show symptoms of many psychiatric disorders like MDD. Handicaps in temperament and character and social problem solving domains are also similar for individuals who attempt suicide. The SPSI may reflect defects in Temperament and Character dimensions in concordance with the cognitive behavioral therapeutic model. The limitations of this study include difficulty in generating a control group, and small sample size. Besides, psychopathologies as confounders might affect the relationships between parameters. Yet this is a preliminary study, we 
we have more comprehensive insight when will get the data from the multi-centric research.

\section{REFERENCES}

1. WHO. Suicide prevention (SUPRE). www.who.int/mental health/prevention/suicide/su icideprevent/en/

2. Kessler RC, Borges G, Walters EE. Prevalence of and risk factors for lifetime suicide attempts in the National Comorbidity Survey. Arch Gen Psychiatry 1999; 56:617-626.

3. Eskin M, Akoğlu A, Uygur B. Traumatic life events and problem solving skills in psychiatric outpatients: relationships with suicidal behavior. Turk Psikiyatri Derg 2006 17:266-275.

4. Pollock LR, Williams JM. Problem solving and suicidal behavior. Suicide Life Threat Behav 1998; 28:375-387.

5. Grover KE, Green KL, Pettit JW, Monteith LL, Garza MJ, Venta A. Problem solving moderates the effects of life event stress and chronic stress on suicidal behaviors in adolescence. J Clin Psychol 2009; 65:1281-1290.

6. Dilli D, Dallar Y, Çakır I. Psychological characteristics of adolescent suicide attempters presenting to a pediatric emergency service. Turk $J$ Med Sci 2010; 40:377-390.

7. Aslan Ş, Emet M, Çakır Z, Aköz A, Akgöl Gür ST. Suicide attempts with amitriptyline in adults: a prospective, demographic, clinical study. Turk J Med Sci 2011; 41:243-249.

8. Becker-Weidman EG, Jacobs RH, Reinecke MA, Silva SG, March JS. Social problem-solving among adolescents treated for depression. Behav Res Ther 2010; 48:11-18.

9. Rudd MD. The suicidal mode: a cognitive-behavioral model of suicidality. Suicide Life Threat Behav 2000; 30:18-33.

10. Wenzel A, Brown GK, Beck AT. Cognitive therapy for suicidal patients: scientific and clinical applications. Washington, DC: American Psychological Association, 2009.

11. D'Zurilla T. Problem-Solving Therapy: A Social Competence Approach to Clinical Intervention. New York: Springer, 1986.

12. D'Zurilla TJ, Nezu AM. Problem-Solving Therapy: A Social Competence Approach to Clinical Intervention. Second ed., New York: Springer, 1999.

13. Sahin N, Sahin N, Heppner PP. Psychometric properties of the Problem Solving Inventory in a group of Turkish university students. Cognit Ther Res 1993; 17:379-396.

14. Blasco-Fontecilla $H$, Baca-Garcia E, Dervic $K$ Perez-Rodriguez MM, Saiz-Gonzalez MD, SaizRuiz J, et al. Severity of personality disorders and suicide attempt. Acta Psychiatr Scand 2009; 119:149-155.

15. Becerra B, Paez F, Robles-Garcia R, Vela GE. Temperament and character profile of persons with suicide attempt. Actas Espanas Psiquiatria 2005; 33:117-122.

16. Van Heeringen K, Audenaert K, Van Laere K, Dumont F, Slegers G, Mertens J, et al. Prefrontal 5-HT2a receptor binding index, hopelessness and personality characteristics in attempted suicide. J Affect Disord 2003; 74:149-158.

17. Van Heeringen $K$, Audenaert K, Van de Wiele L, Verstrate $A$. Cortisol in violent suicidal behaviour: association with personality and monoaminergic activity. J Affect Disord 2000; 60:181-189.

18. Grucza RA, Przybeck TR, Cloninger CR. Personality as a mediator of demographic risk factors for suicide attempts in a community sample. Compr Psychiatry 2005; 46:214-222.

19. Giegling I, Olgiati $P$, Hartmann AM, Calati $R$, Möller HJ, Rujescu D, et al. Personality and attempted suicide. Analysis of anger, aggression and impulsivity. J Psychiatr Res 2009; 43:12621271.

20. First MB, Spitzer RL, Gibbon M. Structured Clinical Interview for DSM-IV Clinical Version (SCIDI/CV). Washington, DC: American Psychiatric Press, 1997.

21. Özkürkçügil A, Aydemir Ö, Yıldız M. DSM-IV Eksen I Bozuklukları için Yapılandırılmış Klinik Görüşmenin Türkçe'ye Uyarlanması ve Güvenirlik Çalışması. Ilaç Tedavi Dergisi 1999; 12:233236.

22. Beck AT. An inventory for measuring depression. Arch Gen Psychiatry 1961; 4:561-571.

23. Hisli N. Beck Depresyon Envanterinin üniversite öğrencileri için geçerliliği, güvenilirliği. Psikoloji Dergisi 1989; 7:3-13.

24. Cloninger CR, Przybeck TR, Svrakic DM, Wetzel $R D$. The Temperament and Character Inventory (TCl): a guide to its development and use. St. Louis, Missouri, Center for Psychobiology of Personality, 1994.

25. Köse S, Sayar K, Ak I, Kalelioğlu Ü, Kırpınar I, Reeves RA, et al. Mizaç ve karakter envanteri (Türkçe TCI): Geçerlilik, güvenirlilik ve faktör yapısı. BCP 2004; 14:107-131.

26. D'Zurilla TJ, Nezu A. M. Development and preliminary evaluation of the Social ProblemSolving Inventory. Psychological Assessment: J Consult Clin Psychol 1990; 2:156-163.

Anadolu Psikiyatri Derg 2014; 15:31-38 
27. Duyan V, Gelbal S. Sosyal Sorun Çözme Envanteri'nin Türkçeye Uyarlama Çalışması. Toplum ve Sosyal Hizmet 2008; 19:7-28.

28. Nock MK, Hwang I, Sampson NA, Kessler RC. Mental disorders, comorbidity and suicidal behavior: results from the National Comorbidity Survey Replication. Mol Psychiatry 2010; 15:868876.

29. Nock MK, Hwang I, Sampson N, Kessler RC, Angermeyer $M$, Beautrais $A$, et al. Cross-national analysis of the associations among mental disorders and suicidal behavior: findings from the WHO World Mental Health Surveys. PLoS Med 2009; 6:e1000123.

30. Siani R, Garzotto N, Zimmermann Tansella C, Tansella M. Predictive Scales for Parasuicide Repetition Further Results. Acta Psychiat Scand 1979; 59:17-23.

31. Kreitman N, Casey P. Repetition of Parasuicide An Epidemiological and Clinical Study. $\mathrm{Br} \mathrm{J}$ Psychiatry 1988; 153:792-800.

32. Corcoran P, Keeley HS, O'Sullivan M, Perry IJ. The incidence and repetition of attempted suicide in Ireland. Eur J Public Health 2004; 14:19-23.

33. Maydeu-Olivares A, D'Zurilla TJ. A factor analysis of the Social Problem Solving Inventory using polychoric correlations, Eur J Psychol Assess 1995; 11:98-107.

34. D'Zurilla TJ, Nezu AM, Maydeu-Olivares A. Social problem solving: theory and assessment. TJ D'Zurilla, EC Chang, LJ Sanna (Eds.), Social Problem Solving: Theory, Research, and Training, Washington, DC: American Psychological Association, 2004, p.11-27.

35. Cloninger CR, Svrakic DM, Przybeck TR. A psychobiological model of temperament and character. Arch Gen Psychiatry 1993; 50:975990.

36. Köse S. A Psychobiological Model of Temperament and Character: TCI. Yeni Symposium 2003; 41:86-97.

37. Svrakic DM, Cloninger CR. Personality disorder. BJ Sadock, VA Sadock (Eds.), Comprehensive Textbook of Psychiatry, eighth ed., Philadelphia, Lippincott Williams \& Wilkins, 2004.

38. Cloninger CR, Svrakic DM. Personality disorders. BJ Sadock, VA Sadock (Eds.), Comprehensive Textbook of Psychiatry, seventh ed., Baltimore: Williams \& Williams, 2000.

39. Ravaja N, Keltikangas-Järvinen L, Kettunen J. Cloninger's temperament dimensions and threat, stress, and performance appraisals during different challenges among young adults. J Pers 2006; 74:287-310.

40. D'Zurilla TJ, Nezu AM, Maydeu-Olivares A. Social Problem Solving Inventory-Revised: Technical Manual. New York: Multi-Health Systems, 2002.

41. Hansenne M, Reggers J, Pinto E, Kjiri K, Ajamier A, Ansseau M. Temperament and character inventtory (TCl) and depression. J Psychiatric Res 1999; 33:31-36.

42. Arkar H. Cloninger'in mizaç ve karakter boyutları ile kişilik bozuklukları arasındaki ilişki. Klinik Psikiyatri Dergisi 2008; 11:115-124.

43. Arkar H. Depresif duygudurum ile kişilik arasındaki ilişki: Beck Depresyon Envanteri ile Mizaç ve Karakter Envanteri'nin karşılaştırılması. New Symposium, 2010; 48:116-121. 